\title{
The Heart of Faith in Graham Greene's The Heart of the Matter
}

\author{
Ali Hamada
}

University of Mosul, Iraq.

\begin{abstract}
There is no question that Graham Greene's The Heart of the Matter is a work that tackles religious faith views. Through the principal character, Major Scobie, Greene tries to show his own concept of true faith. Major Scobie, the police commissioner is put in the divine-earthly balance equation and is left alone to lead up his way.

This paper is an attempt to piece together Graham Greene's ideas around the truth of faith. The strategy adopted in the paper is to follow Major Scobie's words and actions and to put them in the scale of Christian dogma to weigh their truth.

At last, the paper presents the results it attained in the conclusion. It concludes that there is a deal of hypocrisy or self-deception built in the principal character, Major Scobie that extends from the beginning to the end of the novel that affects the truth of faith.
\end{abstract}

Keywords - religious faith views, Graham Greene.

The fact that Graham Greene is a religiously-interested writer is mostly agreed upon by critics, and he himself had asserted the "religious sense," which is "a quality that he claimed was of utmost importance to the modern novel."(1) In this research paper the light is to be shed on Greene's overall thoughts which are to do with faith and religion (Catholicism) and how far he is committed to his thoughts in this respect in an attempt to assess what he achieved through the themes he interwove and the characterization he gave for the central characters. To begin with, it is important to note that two characters are to be observed and scrutinized for getting to a better understanding of how faith and the truth of faith are presented throughout the novel.

First and foremost, the character of the protagonist, Major Henry Scobie is to be checked on. Secondly, the character of the priest, Father Rank is rowed in. As for the character of Scobie, he is presented as a fifty three white tall thinlyhaired English deputy commissioner of police with more than ten years abroad in the service in western Africa. In religious terms, he is described as "a Catholic convert married to a discontented, nagging Catholic wife, Louise."

(2) Over his career, he proved to be a clock-like dedicated person who does his best in the line of duty. Though, he failed for the promotion he waited for long, to become a commissioner. This very thing upsets his wife, Louise, who aspires to more sociability and hence is disappointed thereupon.

At this point, it is important to note that Major Scobie's relationship to his wife is marked by a sense of pity, firstly for he sees that she have lost the 'attractiveness,' and secondly, that they share the same sorrow due to the loss of their only child fourteen years ago. The importance of this detail should be underlined as it contributes to his own downfall.

As for the other woman tangled in his orbit, Helen Rolt, who is a 19-year old widow surviving a torpedoed ship overseas, and who found in him a kind of protection and consolation, the same pity for his wife is equally applicable. Likewise, it is important to underline 'pity' being the tragic flaw for Major Scobie. Critics see that "Greene's treatment of Scobie's marital dilemma focused on the psychological 'sin' of pity and its inevitable consequence."(3)

Carrying on our discussion, it is crucial to approach Major Scobie's character from the viewpoint of the author himself. Philip Stratford, editor of The Portable Graham Greene quotes Greene in the introduction to his novel. Greene states that he wanted to show "the disastrous effect on human beings of pity as distinct from compassion." (4) And he elaborates on the main function of his protagonist's character. He says that "the character of Scobie was intended to show that pity can be the expression of an almost monstrous pride." Hence, Major Scobie unleashes the monster inside of him which was manifested in trespassing the boundaries of his own morality code or Catholicism, beginning from borrowing money from the man he labels 'corrupt', Yusef, the Syrian trader; helping Yusef smuggle diamonds; committing and insisting on going on committing adultery with Helen; looking sideways at the elimination of his own boy servant, Ali whom he described as loyal and good in the beginning; up to the last 'unforgivable sin' as he said, i.e. committing suicide. 
Talking about the monster, it is fair to trace the reasons behind its unleashing. One important thing that can be indicated is that what broke the leash of the monster and led eventually to the series of self-destruction events Major Scobie went through and what triggered the destructive fire in him is missing the promotion to the commissioner post. The hope to get this promotion cost him a lot of hard work, discipline and endurance and hence his life to be requited as such. Losing the promotion signaled and anticipated losing faith in God, in the first place, and disloyalty to the government's regulations seen in lying about the hidden letter found in the Portuguese ship, dealing with Yusef, etc. . After meeting the bank manager to get a loan that he did not manage to get, Scobie walked in the street, without putting his helmet on his head as a kind of punishment to himself. Greene says:

"It seemed to Scobie that he had sowed enough - against what harvest? He couldn't himself have told." (5:227)

To have a better view of Scobie, let us examine these two situations. The first one is that when he opened the hidden letter he caught in the Portuguese ship. Opening it was against the law, though, he wanted to settle it out. $\mathrm{He}$ thought: "There must be some lie to be told, Scobie thought, but he was unaccustomed to lies." (5:53) In this instance we obviously have Greene's opinion of him, or as such Greene demands of us to think of him.

In the same way, the other situation involves Yusef, the Syrian trader. He was talking to Scobie and in the meanwhile giving us an impression about him. He says:

"You nearly caught me, Major Scobie, that time. It was a matter of import duties, you remember. You could have caught me if you had told your policeman to say something a little different. I was quite overcome with astonishment, Major Scobie, to sit in a police court and hear true facts from the mouths of policemen. You must have taken a lot of trouble to find out what was true, and to make them say it. I said to myself, Yusef, a Daniel has come to the Colonial Police.' " (5:91)

Again we have the same sort of information exposed by one of the characters around him that encourages us to have a better view of him and to the same effect.

Moreover, ever since the beginning to the end of the novel Major Scobie insists and asserts that he is a faithful Catholic. Critic G. Chandramohan argues that "He is also obsessively aware of God and His mercy, being a devout Catholic."(6) He declares his faith plainly throughout the story and insists that Catholics like himself are knowledgeable and that they are doomed by their knowledge, foreshadowing his own destiny. He says:
"The trouble is, he thought, we know the answers - we Catholics are damned by our knowledge. There is no need for me to work anything out - there is only one answer." $(5: 219)$

Also, there are many instances in which he monologues supplicating God, confessing his weakness and expressing his dilemma, in a show of faith.

Yet it is significant to focus on the matter of knowledge that Major Scobie refrained other times. Highlighting the matter of knowledge, one can simply judge that knowledge means being competent of the rules, limits and details of something but it does not mean, by any means, being faithful to them.

As a matter of fact, the nature of Major Scobie's character sets a weird contradiction that it allows an overlapping definition. For instance, Gianina Daniela Sabău sees that "Scobie has both something of a sinner and of a saint in him."(7) Two strikingly opposite bearings can be seen in him, something that is inexplicable save in a paradoxical way. This might belong to the author himself and his way of writing. In his book Graham Greene's Catholic Imagination, Mark Bosco writes:

"Greene's paradoxical literary expression of Catholic faith is never offered as a comforting way out of the discomforting realities of modernity. Rather, Catholicism serves to raise the standards, heighten the awareness of the fallen sense of the world, and challenge characters to respond to extreme situations in full knowledge of what is at stake. Religion - and Catholicism in particularinevitably becomes part of Greene's dark and seedy terrain, an imaginative ground from which Greene's creativity draws inspiration.(8)

So, he suggests that Greene is only accessible through understanding the paradoxes he manipulates to serve his aims.

It is really intriguing the amount of arguments that makes a real human protagonist or a premium kind of a sinner of Major Scobie. Andrzej Weselinski of the University of Warsaw, for instance, doubles the 'betrayal' characteristic in him. He says:

"Scobie is a double betrayer, for he betrays God ( the sacrilegious reception of the Eucharist), and his wife (adulterous love affair)." (9)

Reviewing the novel, George Orwell agnostically slams Greene for tailoring his protagonist according to the orthodox measure. He says that Greene appears to "share the idea, which has been floating around ever since Baudelaire, that there is something rather distingué in being damned; Hell is a sort of high-class night club, entry to which is reserved for Catholics only, since the others, the 
non-Catholics, are too ignorant to be held guilty, like the beasts that perish." (10) He carries on criticizing him for not having a better look at his work than the reader's at his thoughts for he sees that the central idea of the book (The Heart of the Matter) is that it is better, spiritually higher, to be an erring Catholic than a virtuous pagan," a frivolous idea that was not well presented.

Religiously speaking, there is an intricate peculiar understanding of the nature of sin in Catholicism which might explain some of the weirdness. The best articulation of this understanding is made by the French catholic poet, Charles Peguy. He states that:

"At the very heart of Christianity is the sinner. No one is more competent on the matter of Christianity than the sinner -- unless it be the saint."(11)

But, this only leads to another question in the case of Major Scobie. The question is on the criterion upon which competence and clinging to it, i.e. faith and its truth are measured. So, is it awareness or willfulness? In The Heart of the Matter, Major Scobie proclaims adherence to Catholicism and in the same time he INSISTS on willfully committing all types of sins that are tabooed by Catholicism till the end of his days. Thus, it does not make sense, at all.

In respect to Major Scobie's dilemma, one can say that his problems stem mainly from a kind of a systemic selfdeception and delusion or maybe hypocrisy. Simply speaking, his outspoken catholic knowledge did not help him favor between the forgivable sin and the 'unforgivable sin,' as he catholically named it. Replying to Fellowes who inquired about the catholic opinion of despair, i. e. committing suicide as Scobie asked Dr. Sykes of the best way out that he recommends, Major Scobie says:

"We are taught, ....., that it's the unforgivable sin." (5:194)

Critic, Michael G. Brennan provides a comprehensive psychological analysis of Major Scobie's character. He suggests that Greene's protagonist, Scobie suffers an apparent "irreversible immersion in self-deceiving despair (that) takes a firm hold over his mind. Faustus-like, Scobie is seduced by a dangerous pride in his own flawed rationality."(12)

Self-deception or/and hypocrisy are evident in many situations in which Major Scobie is involved. In the secret letter he writes to Helen to break up with her, he tells her that he loves her more than himself, his wife and even more than God. He wrote:

"My darling ..... I love you more than myself, more than my wife, more than God I think. I am trying very hard to tell you the truth. I want more than anything in the world to make you happy. ..... I love you. Forgive me." (5:181) while it is only pity that attracted him to her in the first place. And ironically speaking, we can see that he honours this last statement in the decision he made at last by committing suicide against God's teachings.

And despite the fact that he knows that the Syrian merchant, Yusef is corrupt and has a log in smuggling, he resorts to him and borrows money from him and entrusts him his secrets telling him about his concerns in respect to his boy, Ali and a might-be connection to losing the letter that did not reach for Helen.

On the other hand, one characteristic faculty that Major Scobie has is that, one can call, of negative altruism. One critic says that "The protagonists (like Greene's Scobie) are ready to be damned for the sake of others."(13) Unconditionally, we see a character that victimizes itself for the sake of others and for nothing save maybe a desire to be damned, or as a weird penal self-punishment for love of God. One critic tries to present an explanation of this by saying that:

"They become victims of their actions. In this sense, Green's heroes are more victims than heroes. They are often victims of their own love of God. They are caught between pain and despair, and are afraid of damnation (Scobie in The Heart of the Matter for example)."(14)

This negative altruism goes with and supports our presumption that Major Scobie enjoys a willful selfdeception part.

It is worthwhile to have a look at Major Scobie's last reiteration of his Catholicism just before taking the overdose that is supposed to end his life. He meditates:

"O God, I am the only guilty one because I've known the answers all the time. I've preferred to give you pain rather than give pain to Helen or my wife because I can't observe your suffering. I can only imagine it. I can't desert either of them while I am alive, but I can die and remove myself from their blood stream. They are ill with me and I can cure them. And you too, God - you are ill with me; I can't go on, month after month, insulting you. ..... I am going to damn myself, whatever that means. ..... you'll be able to forget me, God, for eternity." (2:258)

In this monologue we can see how far Major Scobie's catholic vision is confused. He admits that he 'preferred' to give pain to God rather than the woman he loved; went on insulting God; and finally he decided to trespass God's will to 'cure' God of him. This only reinforces the self-deception and hypocrisy presumption indicated earlier.

Last but not the least, we should sum up Major Scobie's choices to get to a better judgment of his matter of faith. In the one hand, he has the burden of pity for both his wife, Louise and his mistress, Helen for each he is reluctant or 
unable to leave. While on the other hand, he has his love for God against which he has to make his preference. To elucidate it one can say that Major Scobie must choose, willy-nilly between leaving either of the women or leaving God! Of course, leaving God means damnation, a thing that Major Scobie preferred at last. The nature of this preferred choice denotes that the heart of faith in The Heart of the Matter is foiled by a willful kind of self-deception which turns the protagonist of the novel into an antagonist.

As for the priest, Father Rank, his character can be said to be a contrastive one. Not to linger much on him, one instance is to be examined to show the contrast. In this instance Father Rank exchanges roles with Major Scobie, maybe in a moment of weakness that incurred a violent stream of consciousness, or in an attempt to relieve and condole a heavy soul that he sees in Major Scobie, or it might be for pity, too. One afternoon, he pays Major Scobie a visit and falls to a fit in which he confesses to him his feeling of uselessness which stems from his career as a priest. He says:

"'The dying.' Father Rank said, 'that's what I'm here for.' ..... 'I've never been any good to the living, Scobie.'

'You are talking nonsense, Father.'

'When I was a novice, I thought that people talked to their priests, and I thought God somehow gave the right words. Don't mind me, Scobie, don't listen to me. It is the rains they always get me down about this time. God does give the right words, Scobie. I had a parish once in Northampton. .... I only had to ask and they'd give. I wasn't of any use to a single living soul, Scobie. I thought, in Africa things will be different. You see I am not a reading man, Scobie. I never had much talent for loving God as some people do. I wanted to be of use, that's all. Don't listen to me. It's the rains. .... If people are in trouble they'd go to you, Scobie, not to me. They ask me to dinner to hear the gossip." (5:183)

Summing up the setting and the background of this situation, a priest, an afternoon, rains, and a free association of ideas we can evidently see a void, or a uselessness sense of the catholic code exposed through these two characters.

Looking the other way around, we can argue that Greene's story missed the target if he meant it to be a religiouslyoriented narrative. Saroha and Vasishta argue strongly that:

"Greene found it increasingly difficult to harmonize his experience with Catholic myth, reality with the orthodoxy of belief. Catholicism may have given him emotional anchorage, a sense of belonging but it has not affected his creative pursuit. The new faith might have given him some spiritual assurance but he has not sacrificed experience to the tailor- made dogma of the Church."(15)
Greene's story, though in need of some elaboration in some places, is a story of real human beings who struggle to cover up the ugly face of sinfulness with religiously dyed patches, which takes it to the circle of hypocrisy. For the best, reading Greene's works one evidently sees vivid human beings with their own weaknesses. As Chandramohan says: "one could say that Greene's novels are meant to express human nature rather than to give moral instruction."(16)

Still, if we are to assess Greene's tackling of the subject matter of religion we can say that he succeeded in fielding the 'religious sense' into the atmosphere of the modern novel. Bosco says that "Many Catholic critics of the time championed Greene's work for manifesting their faith in such a popular medium."(17) While others underestimate the attention paid to the religious readings of the his works like John Atkins who sees that "Greene's work is valuable as social commentary and much more as individual (including personal) revelation ... the theology is on the surface, planted there rather weightily but it is a surface growth."(18) Yet, the much debate he incited within the literary and the theological circles proves positive in his side.

\section{REFERENCES}

[1] Mark Bosco. Graham Greene's Catholic Imagination (Oxford: OUP, 2005). P. 10.

[2] Bernard Bergonzi. A Study in Greene. (New York: OUP, 2006). P. 117.

[3] Michael G. Brennan. Graham Greene Fictions, Faith And Authorship (London: Continuum, 2010). P. 83.

[4] Philip Stratford (ed.). The Portable Graham Greene,( New York: Viking Press 1973), p. 100.

[5] Graham Greene. The Heart of the Matter. (New York: Penguin Books, 1982). PP.

[6] G. Chandramohan. Saintly Sinners: A Review of Graham Greene's Protagonists. The Indian Review of World Literature in English, Vol. 1, No. I - Jan, 2005. P. 2.

[7] Gianina Daniela Sabău. A Psychoanalytic Reading of Graham Greene's The Heart of the Matter. "Vasile Goldiș" Western University of Arad, Romania. P. 5.

[8] Ibid. 1. P. 5.

[9] Andrzej Weselinski. Irony and Melodrama in The Heart of the Matter. University of Warsaw.

[10] George Orwell. The Sanctified Sinner. Review of 'The Heart of the Matter' by Graham Greene. The New Yorker. July 17 1948. P. 61. 
[11] Quoted in: Michael Novak. A New Vision of Man: How Christianity Has Changed Political Economy. May 1995. Volume 24. Number 5.

[12] Ibid. 3. P. 85.

[13] Ibid. 6. P. 2.

[14] Ibid. 6. P. 3.

[15] Alka Saroha \& S K Vasishta. Religious Vision in the Works of Graham Greene. The Criterion An International Journal in English ISSN 0976-8165. P. 3.

[16] Ibid. 6. P. 3.

[17] Ibid. 1. P. 5.

[18] John Atkins. Graham Greene. (London: Calder \& Boyars, 1966). P. 34. 